\title{
Comparative study of mental health and quality of life in long term refugees and host populations in Oru-ljebu, Southwest Nigeria
}

\author{
Oluwaseun O Akinyemi ${ }^{*}$, Eme T Owoaje ${ }^{2}$, Olusimbo K Ige ${ }^{1}$ and Oluwafemi A Popoola ${ }^{1}$
}

\begin{abstract}
Background: Refugees as "People Living in Highly Stressful Situation" are particularly vulnerable to mental ill-health as a result of the trauma experienced pre- and post-migration. The lack of information on the mental health disparities of refugees and non-refugees in West Africa is what this study aimed to bridge. A cross-sectional study design was employed using a cluster sampling technique. Interviewer-administered structured questionnaires consisting of the Mini-International Neuropsychiatric Interview (MINI), WHO quality of life (WHOQOL-BREF) and the Community Quality of Life (CQoL) were used for data collection. Data were analyzed with SPSS version 17. Logistic regression analysis was used to determine the predictors of mental health status and QoL.

Results: Respondents consisted of 444(45.7\%) refugees and 527(54.3\%) non-refugees. Two-thirds 292 (66\%) of the refugees were Liberians. Mean age: refugees $-34.8 \pm 12.8$ years versus non-refugees $-33.3 \pm 8.1$ years $(p<0.05)$. While the majority $376(84.7 \%)$ of the refugees were married, most $468(88.8 \%)$ of the native population were not $(p<0.001)$. Significantly higher proportion of refugees had polygamous marriages, lived in poorer type of accommodation and had no formal education compared to the non-refugees $(p<0.05)$. The overall QoL and CQoL scores were both significantly lower for the refugees $(p<0.001)$. Refugees were three times more likely than nonrefugees to have poor mental health [OR: $3.43 ; 95 \% \mathrm{Cl}: 1.83-6.40]$. Overall, being currently ill tripled the odds of mental ill health [OR: 2.73; 95\%Cl: 1.98-3.77]. Unskilled workers [OR: 2.78; 95\%Cl: 1.68-4.60], skilled workers [OR: 2.98; 95\% Cl: 2.03-4.38] and the unemployed [OR: 1.94; 95\%Cl: 1.29-2.92] had two or more times the odds of poor mental health compared to professionals.
\end{abstract}

Conclusions: QoL and occupational status were the major threats to the mental health of the refugees. Results of this study point to the need for continued attention to not only the healthcare needs but the welfare, housing, employment and overall QoL to support the long-term mental health of refugees and non-refugee populations alike.

Keywords: Mental health, Quality of Life, Refugees, Nigeria

\section{Background}

Eliminating health disparities and increasing the quality and years of healthy life for all people is a global goal. To achieve these, identifying and addressing the health needs of populations that are often overlooked need to be prioritised. Refugees as "People Living in Highly Stressful Situation" are particularly vulnerable to mental

\footnotetext{
* Correspondence: seunakinyemi@hotmail.com

${ }^{1}$ Department of Community Medicine, University College Hospital, Ibadan, Nigeria

Full list of author information is available at the end of the article
}

ill-health as a result of the trauma experienced pre- and post-migration [1-3]. Although literature abounds on the mental health disparities of refugees and non-refugees in many regions of the world, the lack of information on refugee communities in West Africa is notable [4]. In a meta-analysis of pre- and post- migration factors associated with mental ill-health among refugees, only two of the 59 independent comparisons of refugee and nonrefugee populations in adults from the same low-income country were compared and none was from Africa [5]. Although Africans constitute only 12 per cent of the

\section{Biomed Central}


global population [6], about a quarter of the world's 8.8 million refugees are in Africa; 150,000 of whom live in West Africa [6].

Apart from the trauma which drove many into exile post migration factors have also been linked to the excess burden of mental health problems borne by refugees [7]. Therefore, increasing attention is now being drawn to the conditions in which refugees live in exile and the long-term mental health of refugees in exile. The mental health status of refugees in Sub-Saharan Africa is of particular interest because of the poorer quality of life (QoL) of the region compared to other regions of the world [8]. The QoL, though subjective as an indicator of well-being has been shown to be inextricably associated with the mental health status [1,3]. It is yet to be documented if refugees in host communities with similar culture and living conditions fare better than those in richer countries. The added dimension of the community quality of life (CQoL) which is the perception of "being", "belonging" and "becoming" a part of the community in which one lives may also have consequences for mental morbidity [3]. The research questions in focus in the present study are: Do disparities exist in the mental health status of refugees and non-refugee populations in Nigeria? Would the QoL and CQoL also differ and would such disparities be sufficient to threaten the mental well-being of refugees in excess of the nonrefugee population? This study aimed at providing community-based comparative assessment data on the mental health status and its interaction with the QoL and CQoL of refugees who have been long term residents in Oru-Ijebu South West Nigeria compared with the non-refugee population. The study's hypothesis was: there is no difference in the mental health and QoL of refugees and non-refugees in Southwest Nigeria.

\section{Methods \\ Study area}

This study was conducted in Oru-Ijebu, Ogun State, South-western Nigeria. Oru-Ijebu, which borders AgoIwoye, a university town, is a semi-urban town which according to the 2006 census had a population of 27,000 [9]. The Oru Refugee Camp is located on the outskirts, about $500 \mathrm{~m}$ to Oru town. The Camp which is the only one in the country was established in October 1990 as an initiative of the United Nations High Commissioner for Refugees (UNHCR) with the approval of the Federal Government of Nigeria and in collaboration with the Nigerian Red Cross Society $[9,10]$. The camp was established as an aftermath of the Liberian civil war in 1989 and many of the refugees have been resident in the camp since then. Nationalities represented in the Camp included Liberians, Sierra-Leoneans and Togolese. Health and social welfare benefits were withdrawn and the camp was officially closed in 2007 in order to encourage voluntary repatriation of the refugees. Many of the refugees however chose to remain in the camp. There are about 5,000 refugees currently living in the camp, majority of whom are Liberians. The Camp is made up of 11 residential blocks consisting of 72 houses of two bedroom units. Many other makeshift mud houses have been constructed by the refugees over the years. There is a non-functional mini clinic and one primary school of eight classrooms. Some of the refugees were involved in vocations like hairdressing, trading, transportation using motorcycles, teaching and clerical work within and outside the camp.

\section{Study population}

The study population comprised of male and female residents of Oru community and the refugee camp aged 18 years and above who have resided in the area for at least one year prior to the study.

Ethical approval for this study was obtained from the University of Ibadan/University College Hospital Institutional Review Committee before study was commenced. Written informed consent was also obtained from participants before administering questionnaires. A crosssectional study design was used comparing refugees with non-refugees within the same geographical location. The minimum sample size estimated to compare the proportions with poor mental health status was based on a prior estimate of $22 \%$ for poor mental health [11]. An expected difference of $15 \%$ was used, at $95 \%$ confidence interval, $80 \%$ power and $15 \%$ precision. This was adjusted by a factor of two for clustering effect; and allowance was made for $10 \%$ non-response. A sample size of 431 per group was thus estimated. A cluster sampling technique was used to obtain a representative sample of the refugee and non-refugee communities. Adults aged 18 years and above were selected from the Oru community and the refugee camp. For the non-refugees, four enumeration areas (clusters) were chosen by balloting from the 60 enumeration areas in Oru-Ijebu. Each enumeration area had 15-30 houses with about 5-11 adults per house. All eligible adults in each enumeration area were interviewed. For the refugees, eight residential blocks were selected by balloting from the 11 blocks in the refugee camp. All eligible respondents in the 10 houses (each consisting of four to five two-bedroom units) present in each selected block were interviewed.

\section{Study instruments}

Interviewer-administered structured questionnaires consisting of the Mini-International Neuropsychiatric Interview (MINI) [12], WHO quality of life (WHOQOLBREF) [13] and the Community Quality of Life adapted from the Florida MAPP Field Guide [14], were used for 
data collection. The Cronbach's alphas were 0.86, 0.93 and 0.93 respectively. The assessment of clinical variables such as suicide ideation, visual hallucination, drug and alcohol abuse, mania, posttraumatic stress disorder (PTSD), obsession and depression was done using respondents' responses to specific questions on the MINI.

\section{Measures}

\section{Quality of life}

The World Health Organization quality-of-life group defined health-related quality of life as the individual's subjective evaluation of disease and impairment and disabilities [13]. The quality of life was measured with the WHOQOL-BREF with 26 questions which were measured on a 5 point Likert scale. Scores were scaled in a positive direction (i.e. higher scores denoting higher quality of life) and summed. The WHOQOL-BREF was developed to be applicable in diverse cultural settings and was designed across several countries including one in Sub-Saharan Africa [15].

\section{Mental health}

Defined as a state of well-being in which every individual realizes his or her own potential, can cope with the normal stresses of life, can work productively and fruitfully, and is able to make a contribution to her or his community [16]. Mental health was assessed using the MiniInternational Neuropsychiatric Interview (MINI). MINI has been used in a similar environment and validated in Nigeria, the interrater reliability (Cohen's kappa) was 0.86 [17]. The MINI consists of 26 questions with "Yes" or "No" responses. "Yes" was scored one and "No" zero (0). Scores were summed and Score $\leq 5$ were labeled as green zone (good mental health), scores 6-8 fell into the yellow zone (borderline) and scores 9-24 fell in the red zone (poor mental health). These three zones were dichotomised for the purpose of logistic regression analysis; the Green zone, and the Red (i.e. a combination of the Yellow and Red zones [13,18].

\section{Community quality of life}

Is the assessment of the quality of life within a community - understanding a community from the members' point of view [19]. Community QoL was assessed using the Community QoL questionnaire. The instrument consisted of 12 questions which elicits responses through a Likert scale (i.e., 1 to 5 with 1 being low and 5 being high) [14] Each participant's score was summed.

\section{Disability}

Defined as any impairment that can make performing an everyday task more difficult. Disability and physical illness were assessed through self-report.

\section{Data analysis}

Data was collected in August 2010 and analyzed with SPSS version 17. The mean scores for the QoL and CQoL were compared with the Student $t$-test. The determinants of mental health status and QoL were explored using logistic regression analyses. The -2Log Likelihood value was used to assess what model had the best fit. Results are presented as odds ratios (OR) with 95\% confidence limits.

\section{Results}

\section{Socio-demographic characteristics of respondents}

Response rate was $98.9 \%$, consisting of $444(45.7 \%)$ refugees and 527(54.3\%) non-refugees. The mean length of stay of refugees in the Camp was $8.6 \pm 4.8$ years. Table 1 shows the socio-demographic characteristics of respondents. The refugees were slightly older with a mean age of $34.8 \pm 12.8$ years versus $33.3 \pm 8.1$ years for the non-refugee population $(\mathrm{p}<0.05)$. The sex distribution was not significantly different. While the majority 376 (84.7\%) of the refugees were married, most $468(88.8 \%)$ of the native population were not $(\mathrm{p}<0.001)$. Significantly higher proportion of refugees had polygamous marriages, lived in poorer type of accommodation and had no formal education compared to the nonrefugees. The occupations of both populations did not differ significantly.

\section{Ethnicity of indigenes and the nationality of refugees}

Two-thirds, 292 (66\%), of the refugees were Liberians, other nationalities represented were Sierra-Leoneans, 143 (33\%), and Togolese, 3 (1\%). Of the non-refugees, majority 427 (81\%) were of Yoruba ethnicity.

\section{Health status by respondent status}

Table 2 shows health status by respondent category. A significantly higher proportion of non-refugee respondents reported physical disability like chronic back pain and joint pain, 159(30.2\%) versus 84(18.9\%) ( $<<0.001)$. There was however no statistically significant difference between refugees, 151(43.0\%), and non-refugees, 209(39.7\%), who reported current health problems $(\mathrm{p}>0.05)$.

\section{Disparities in the quality of life (QoL) and CQoL profile of respondents}

The QoL profile of respondents based on scores from the WHOQOL-BREF is shown in Table 3. The mean QoL scores for each of the four domains examined were significantly lower for the refugees. The overall QoL and CQoL scores were both significantly lower for the refugees $(\mathrm{p}<0.001)$. 
Table 1 Socio demographic characteristics of respondents

\begin{tabular}{|c|c|c|c|c|}
\hline \multirow[t]{2}{*}{ Variable } & \multirow{2}{*}{$\frac{\text { Refugee }(\mathrm{N}=444)}{\text { Frequency }(\%)}$} & \multirow{2}{*}{$\frac{\text { Non-refugee }(\mathrm{N}=527)}{\text { Frequency }(\%)}$} & \multirow[t]{2}{*}{$x^{2}$} & \multirow[t]{2}{*}{ p-value } \\
\hline & & & & \\
\hline \multicolumn{5}{|l|}{ Age (years) } \\
\hline$<25$ & $97(21.8)$ & 61 (11.6) & & \\
\hline $25-34$ & $167(37.6)$ & $286(54.3)$ & 55.7 & $<0.001$ \\
\hline $35-44$ & $90(20.3)$ & $134(25.4)$ & & \\
\hline$>=45$ & $90(20.3)$ & $46(8.7)$ & & \\
\hline \multicolumn{5}{|l|}{ Sex } \\
\hline Male & $263(59.2)$ & $320(60.7)$ & 0.22 & 0.64 \\
\hline Female & $181(40.8)$ & 207 (39.3) & & \\
\hline \multicolumn{5}{|l|}{ Marital status } \\
\hline Never Married & $13(2.9)$ & 468(88.8) & & \\
\hline Married & $376(84.7)$ & $48(9.1)$ & 711.6 & $<0.001$ \\
\hline Divorced & $28(6.3)$ & $5(0.9)$ & & \\
\hline Widowed & $27(6.1)$ & $6(1.1)$ & & \\
\hline Family type & $\mathrm{n}=376$ & $n=48$ & & \\
\hline Monogamous & $256(68.1)$ & $37(77.1)$ & 7.9 & 0.007 \\
\hline Polygamous & $120(31.9)$ & $11(22.9)$ & & \\
\hline \multicolumn{5}{|l|}{ Religion } \\
\hline Christianity & $310(69.8)$ & $383(72.7)$ & & \\
\hline Islam & $134(30.2)$ & $144(27.3)$ & 0.962 & 0.345 \\
\hline \multicolumn{5}{|l|}{ Actively Religious } \\
\hline Yes & $314(70.7)$ & 467(88.6) & 49.03 & $<0.001$ \\
\hline No & 130(29.3) & $60(11.4)$ & & \\
\hline \multicolumn{5}{|l|}{ Housing } \\
\hline One room & 399(89.9) & 254(48.2) & 189.96 & $<0.001$ \\
\hline Two or more rooms & $45(10.1)$ & 273(51.8) & & \\
\hline \multicolumn{5}{|l|}{ Educational status } \\
\hline No formal education & $64(14.4)$ & $13(2.5)$ & 138.56 & $<0.001$ \\
\hline Primary education & $42(9.5)$ & $18(3.4)$ & & \\
\hline Secondary education & $232(52.3)$ & 190(36.1) & & \\
\hline Tertiary education & 106(23.9) & $306(58.1)$ & & \\
\hline \multicolumn{5}{|l|}{ Occupation } \\
\hline Professional & 133(30.0) & $141(26.8)$ & 4.94 & 0.294 \\
\hline Skilled worker & $44(9.9)$ & $68(12.9)$ & & \\
\hline Student & $92(20.7)$ & $122(23.1)$ & & \\
\hline Unemployed & 48(10.8) & $44(8.3)$ & & \\
\hline Unskilled worker & 127(28.6) & 152(28.8) & & \\
\hline
\end{tabular}

\section{Mental health disparities}

Figure 1 shows the reported symptoms of mental illhealth as assessed by the MINI. The most commonly reported symptoms among the refugees was depression (45.3\%), $\mathrm{p}<0.05$, followed by obsession (34\%), $\mathrm{p}<0.05$, Post Traumatic Stress Disorder (34\%), p $<0.05$ and mania (25.9\%). Suicidal ideation was the least reported (11\%), $\mathrm{p}>0.05$, whereas auditory hallucination (27.1\%), visual hallucination (25.6\%) and alcohol abuse (19\%) were commoner among the refugee population $(\mathrm{p}<0.05)$.

\section{Mental health profile of respondents}

Table 4 shows the mental health profile of respondents. A significantly higher proportion of the refugees, 275 $(61.9 \%)$, were in the red zone compared to the nonrefugees $183(34.7)(\mathrm{p}<0.001)$. 
Table 2 Health status by respondent category

\begin{tabular}{lccccc}
\hline Variable & $\begin{array}{l}\text { Refugee } \\
(\mathbf{N}=\mathbf{4 4 4 )}\end{array}$ & & $\begin{array}{c}\text { Non-refugee } \\
\mathbf{( N = 5 2 7 )}\end{array}$ & $x^{\mathbf{2}}$ & p-value \\
\cline { 2 - 3 } & Frequency (\%) & & Frequency (\%) & & \\
\hline Physical disability & & & & & \\
\hline Yes & $84(18.9)$ & & $159(30.2)$ & 16.3 & $\mathrm{p}<0.001$ \\
\hline No & $360(81.1)$ & $368(69.8)$ & & \\
\hline Current illness & & & & & \\
\hline Yes & $151(34.0)$ & $209(39.7)$ & 3.3 & 0.069 \\
\hline No & $293(66.0)$ & $318(60.3)$ & & \\
\hline
\end{tabular}

\section{Predictors of poor mental health status among} respondents

The predictors of poor mental health following logistic regression analysis are presented in Table 5. Refugees were three times more likely than non-refugees to have poor mental health. Being currently ill tripled the odds of mental ill health. Unskilled workers, skilled workers and the unemployed had two or more times the odds of poor mental health compared to professionals.

The determinants of poor mental health among refugees are shown in Table 6. Being engaged in unskilled occupations significantly increased the likelihood of poor mental health. The likelihood of poor mental health decreased by 0.9 for each rise in QoL score.

The factors associated with poor mental health among the non refugee population are shown in Table 7. Risk

Table 3 Quality of Life (QoL) profile of respondents

\begin{tabular}{|c|c|c|c|c|}
\hline Variable & $\mathrm{N}$ & Mean \pm SD & $T$ test & p-value \\
\hline \multicolumn{5}{|l|}{ QoL domains } \\
\hline \multicolumn{5}{|c|}{ Physical health } \\
\hline Refugee & 444 & $19.45 \pm 4.18$ & 17.14 & $<0.001$ \\
\hline Non-refugee & 527 & $23.83 \pm 3.78$ & & \\
\hline \multicolumn{5}{|l|}{ Psychological } \\
\hline Refugee & 444 & $16.86 \pm 4.04$ & 17.16 & $<0.001$ \\
\hline Non-refugee & 527 & $20.98 \pm 3.44$ & & \\
\hline \multicolumn{5}{|c|}{ Social relationship } \\
\hline Refugee & 444 & $8.66 \pm 2.59$ & 14.86 & $<0.001$ \\
\hline Non-refugee & 527 & $10.87 \pm 2.04$ & & \\
\hline \multicolumn{5}{|l|}{ Environment } \\
\hline Refugee & 444 & $26.09 \pm 5.03$ & 29.08 & $<0.001$ \\
\hline Non-refugee & 527 & $26.09 \pm 4.57$ & & \\
\hline \multicolumn{5}{|c|}{ Total QoL Score } \\
\hline Refugee & 444 & $67.47 \pm 13.46$ & 25.89 & $<0.001$ \\
\hline Non-refugee & 527 & $89.47 \pm 2.95$ & & \\
\hline \multicolumn{5}{|l|}{ CQoL Score } \\
\hline Refugee & 444 & $21.64 \pm 5.54$ & 15.15 & $<0.001$ \\
\hline Non-refugee & 527 & $30.64 \pm 11.44$ & & \\
\hline
\end{tabular}

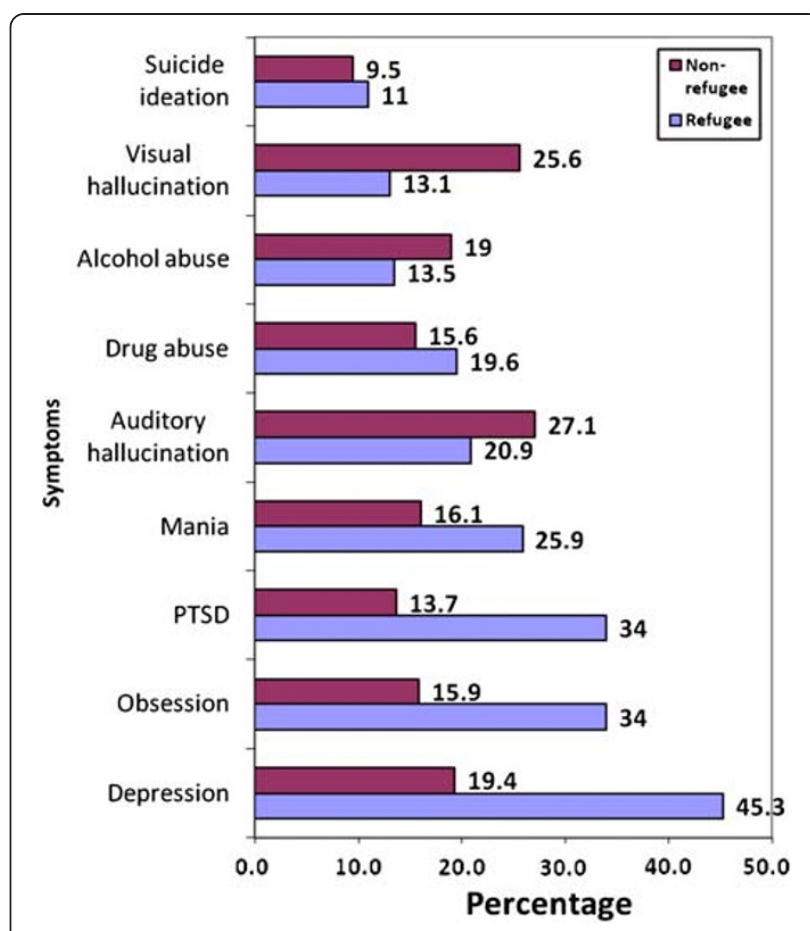

Figure 1 Proportion of respondents reporting mental health disorders by status.

factors were: increasing age, male gender, current illness, being religious, poorer QoL scores, higher CQoL scores and employment as an unskilled or skilled worker.

\section{Discussion}

After an average stay of about a decade in exile, there persisted marked disparities between the mental health status of refugees and non-refugees in Nigeria. These findings correspond to those of previous studies of refugee and non-refugee populations [7,20,21]. The finding that the non-refugee population is very highly educated could be due to the proximity of the study area to a university town, thus a good number of the residents of Oru-Ijebu are university students and workers. The high prevalence of manic symptoms, obsessive compulsive symptoms, depression and Post Traumatic Stress Disorder (PTSD) among refugees in excess of indigenes has also been documented [6,16,22-24]. Although the prevalence of psychiatric symptoms (visual and auditory

Table 4 Mental health profile of respondents

\begin{tabular}{|c|c|c|c|c|}
\hline \multirow[t]{2}{*}{ Variable } & \multirow{2}{*}{$\frac{\text { Refugee }(\mathrm{N}=444)}{\text { Frequency }(\%)}$} & \multirow{2}{*}{$\frac{\text { Non-refugee }(\mathrm{N}=527)}{\text { Frequency }(\%)}$} & \multirow[t]{2}{*}{$x^{2}$} & \multirow[t]{2}{*}{$p$-value } \\
\hline & & & & \\
\hline \multicolumn{5}{|c|}{ MINI Zone } \\
\hline Green & $169(38.1)$ & $344(65.3)$ & 71.6 & $<0.001$ \\
\hline Yellow & $126(28.4)$ & $85(16.1)$ & & \\
\hline Red & 149 (33.6) & 98 (18.6) & & \\
\hline
\end{tabular}


Table 5 Factors associated with poor mental health among all respondents

\begin{tabular}{llll}
\hline Characteristics & $\begin{array}{c}\text { Odds } \\
\text { ratio }\end{array}$ & \begin{tabular}{c}
$\mathbf{9 5 \% \text { Confidence }}$ \\
\cline { 2 - 3 } Age (years)
\end{tabular} & p-value \\
\hline$<25$ & 0.54 & $0.29-1.01$ & 0.055 \\
\hline $25-34$ & 0.86 & $0.52-1.41$ & 0.548 \\
\hline $35-44$ & 1.14 & $0.69-1.90$ & 0.611 \\
\hline$>=45$ & 1 & & \\
\hline Sex & & & \\
\hline Male & 1.07 & $0.80-1.43$ & 0.622 \\
\hline Female & 1 & & \\
\hline
\end{tabular}

\section{Family type}

Monogamous

0.76

$0.56-1.04$

0.083

Polygamous

Religion

\begin{tabular}{llll}
\hline Christianity & 0.90 & $0.65-1.24$ & 0.516 \\
\hline Islam & 1 & &
\end{tabular}

\section{Actively Religious}

\begin{tabular}{llll}
\hline Yes & 1.08 & $0.74-1.58$ & 0.692 \\
\hline No & 1 & & \\
\hline Housing & & & \\
\hline One room & 0.72 & $0.49-1.05$ & 0.087 \\
\hline Two or more rooms & 1 & & \\
\hline Educational status & & & 0.517 \\
\hline No formal education & 0.81 & $0.43-1.54$ & 0.584 \\
\hline Primary education & 0.83 & $0.41-1.64$ & 0.088 \\
\hline Secondary education & 1.39 & $0.95-2.04$ & \\
\hline Tertiary education & 1 & & 0.001 \\
\hline Marital status & & & 0.018 \\
\hline Married & 1.86 & $1.29-2.68$ & \\
\hline Never married & 1.73 & $1.08-2.77$ & \\
\hline Divorced/widowed & 1 & & 0.001 \\
\hline Occupation & & & $<0.001$ \\
\hline Unskilled worker & 2.78 & $1.68-4.60$ & \\
\hline Unemployed & 1.94 & $1.29-2.92$ & \\
\hline Student & 0.33 & $0.77-2.21$ & $2.03-4.38$ \\
\hline Skilled worker & 2.98 & & \\
\hline Professional & 1 & & \\
\hline Status & & & \\
\hline
\end{tabular}

\section{Status}

\begin{tabular}{llll}
\hline Refugees & 3.43 & $1.83-6.40$ & $<0.001$ \\
\hline Non-refugees & 1 & & \\
\hline Current illness & & & \\
\hline Yes & 2.73 & $1.98-3.77$ & $<0.001$ \\
\hline No & 1 & & \\
\hline QoL Score & 0.98 & $0.97-0.99$ & 0.001 \\
\hline CQoL Score & 1.03 & $1.01-1.05$ & 0.001 \\
\hline
\end{tabular}

\begin{tabular}{lll}
\hline CQOL Score & 1.03 & 0.001 \\
\hline
\end{tabular}

Table 6 Factors associated with poor mental health among refugees

\begin{tabular}{llll}
\hline Characteristics & $\begin{array}{l}\text { Odds } \\
\text { ratio }\end{array}$ & \begin{tabular}{c}
$\mathbf{9 5 \% \text { Confidence }}$ \\
\cline { 3 - 4 }
\end{tabular} & p-value \\
\hline Age (years) & & & \\
\hline$<25$ & 0.87 & $0.37-2.01$ & 0.737 \\
\hline $25-34$ & 1.59 & $0.81-3.14$ & 0.180 \\
\hline $35-44$ & 1.79 & $0.90-3.57$ & 0.098 \\
\hline$>=45$ & 1 & & \\
\hline Sex & & & \\
\hline Male & 0.87 & $0.57-1.32$ & 0.501 \\
\hline Female & 1 & & \\
\hline
\end{tabular}

\section{Family type}

\begin{tabular}{llll}
\hline Monogamous & 0.90 & $0.59-1.39$ & 0.644 \\
\hline Polygamous & 1 & & \\
\hline Religion & & & \\
\hline Christianity & 0.91 & $0.59-1.40$ & 0.658 \\
\hline Islam & 1 & &
\end{tabular}

\section{Actively Religious}

\begin{tabular}{llll}
\hline Yes & 0.82 & $0.51-1.32$ & 0.417 \\
\hline No & 1 & & \\
\hline
\end{tabular}

\section{Housing}

\begin{tabular}{llll}
\hline One room & 0.69 & $0.35-1.38$ & 0.295 \\
\hline Two or more rooms & 1 & & \\
\hline Educational status & & & 0.522 \\
\hline No formal education & 0.78 & $0.37-1.66$ & 0.741 \\
\hline Primary education & 0.867 & $0.37-2.02$ & 0.889 \\
\hline Secondary education & 0.96 & $0.56-1.67$ & \\
\hline Tertiary education & 1 & & 0.630 \\
\hline Marital status & & & 0.348 \\
\hline Married & 1.16 & $0.63-2.14$ & \\
\hline Never married & 1.34 & $0.73-2.47$ & 0.045 \\
\hline Divorced/widowed & 1 & & 0.008 \\
\hline Occupation & & & 0.796 \\
\hline Unskilled worker & 2.19 & $1.04-4.61$ & \\
\hline Unemployed & 2.20 & $1.23-3.93$ & 0.001 \\
\hline Student & 0.91 & $0.46-1.81$ & 0.014 \\
\hline Skilled worker & 2.82 & $1.64-4.85$ & \\
\hline Professional & 1 & & \\
\hline Current illness & & $1.12-2.78$ & \\
\hline Yes & 1.77 & $0.96-0.99$ & -1.62 \\
\hline No & 1 & & \\
\hline QoL Score & 0.98 & & \\
\hline CQoL Score & 0.95 & & \\
\hline & & & \\
\hline
\end{tabular}

hallucinations) in this study was higher than previously reported in the country [25], they are however similar to reports from developed countries [26,27]. The reason for this observation is unclear though it may be due to differences in methodologies as MINI is a screening tool 


\begin{tabular}{|c|c|c|c|}
\hline \multirow[t]{2}{*}{ Characteristics } & \multirow{2}{*}{$\begin{array}{l}\text { Odds } \\
\text { ratio }\end{array}$} & 95\% Confidence & \multirow[t]{2}{*}{ p-value } \\
\hline & & Interval & \\
\hline \multicolumn{4}{|l|}{ Age (years) } \\
\hline$<25$ & 0.28 & $0.09-0.87$ & 0.029 \\
\hline $25-34$ & 0.25 & $0.10-0.64$ & 0.004 \\
\hline $35-44$ & 0.37 & $0.14-0.93$ & 0.035 \\
\hline$>=45$ & 1 & & \\
\hline \multicolumn{4}{|l|}{ Sex } \\
\hline Male & 1.67 & $1.05-2.64$ & 0.030 \\
\hline Female & 1 & & \\
\hline
\end{tabular}

\begin{tabular}{|c|c|c|c|}
\hline Family type & & & \\
\hline Monogamous & 0.60 & $0.37-0.97$ & 0.035 \\
\hline Polygamous & 1 & & \\
\hline \multicolumn{4}{|l|}{ Religious activities } \\
\hline Religious & 3.55 & $1.47-8.56$ & 0.005 \\
\hline Not religious & 1 & & \\
\hline \multicolumn{4}{|l|}{ Housing } \\
\hline One room & 0.78 & $0.46-1.32$ & 0.350 \\
\hline Two or more rooms & 1 & & \\
\hline \multicolumn{4}{|l|}{ Current illness } \\
\hline Yes & 5.40 & $3.28-8.90$ & $<0.001$ \\
\hline No & 1 & & \\
\hline$\overline{\mathrm{QoL}}$ & 0.97 & $0.95-0.99$ & 0.001 \\
\hline CQoL & 1.03 & $1.01-1.05$ & 0.013 \\
\hline \multicolumn{4}{|l|}{ Marital status } \\
\hline Married & 2.30 & $1.28-4.18$ & 0.006 \\
\hline Never married & 0.67 & $0.24-1.87$ & 0.450 \\
\hline Divorced/widowed & 1 & & \\
\hline \multicolumn{4}{|l|}{ Occupation } \\
\hline Unskilled Worker & 3.49 & $1.64-7.41$ & 0.001 \\
\hline Unemployed & 1.51 & $0.79-2.90$ & 0.214 \\
\hline Student & 2.05 & $0.89-4.71$ & 0.93 \\
\hline Skilledworker & 2.92 & 1.59- 5.38 & 0.001 \\
\hline Professional & 1 & & \\
\hline
\end{tabular}

designed particularly for the use of non-specialised interviewers $[12,28,29]$.

Disparities also emerged in the QoL and CQoL across all domains. This replicates findings among refugee populations in the USA and Sweden [30-32]. The observed disparity in mental health status persisted after adjusting for QoL, CQoL and socio-demographic variables. While better QoL emerged as protective as seen in other studies [13,30,33-36], increasing CQoL scores appeared to increase the probability for mental health problems. This is at variance from what has been previously documented $[2,11,37]$. The explanation for this is not clear but might be indicative of a sense of collective social suffering. However the marginal increased probability of mental ill health precludes firm conclusions and warrants further evaluation. Physical health status, marital status and employment status emerged as important covariates for all respondents. The impact of poor physical health and lower occupational status on both refugee and indigenous study groups is consistent with reports from other authors [34,38-40].

Within group evaluation revealed that the influence of QoL on both populations was comparable although the adverse impact of higher CQoL scores on mental health was restricted to the non-refugee population. Unlike the refugees many other factors such as increasing age, male gender and being religious affected the mental health of the native population. An overlap in the mental and physical functions was also evident among the native population. The risk factors for the indigenous population were similar to the findings of a previous Nigerian study [34].

Surprisingly, non-refugees reported more physical disability (although not statistically significant) compared with the refugees. A possible explanation for this observation could be the healthy worker's bias [41-43]. Refugees could in fact be healthier than the native population, for them to have survived long distances from their countries of origin under adverse conditions whereas more disabled non-refugees are not able to move and leave their countries. This observation could also be due to sample selection bias $[44,45]$.

Unlike other reports [5], acculturative stressors (CQoL) were not associated with greater mental symptoms among refugees neither was the number of years since resettlement. The major threats to the mental health of the refugees were the QoL and occupational status. These factors however had even less impact than they did on the non-refugee population. The singular factor to which mental health disparity could be ascribed was therefore in being a refugee. This could be a combination of pre- and post-migration trauma which leaves a lasting mark that persists even after decades in exile. While little can be done to alter refugees' pre-migration experiences, public policies can affect many postmigration experiences in order to mitigate the negative health consequences associated with resettlement. Results of this study point to the need for continued attention to not only the healthcare needs but the welfare, housing, employment and overall quality of life to support the long-term mental health of refugees and non-refugee populations alike.

\section{Limitations}

The cross-sectional nature of the survey did not allow for inferences to be drawn as to causal relationship among variables. Also, the self-reported nature of the 
data means they were subjective; although participant's own view is necessary, the question arises whether it is sufficient $[46,47]$. The refugee population is also a very peculiar one with all its support taken away, thus the possibility of a selection bias in this study. It is however important to note that the majority of refugees in this camp did not take up the option of repatriation to their country of initial origin. The refugee study population was therefore similar in age, gender and country of origin to the original camp profile. Furthermore, the non-refugee population might not be very representative of the wider Nigerian society as more than half of the samples are very highly educated. Despite these limitations, the study provides unique insights into the mental health and quality of life of refugees and Nigerians in Oru-Ijebu which is useful in planning community health services.

\section{Conclusions}

The major factors associated with poor mental health among the refugees were the QoL and occupational status. These factors however had even less impact than they did on the native population. Thus, being a refugee seems to be the most important factor to which mental health disparity could be associated. Results of this study point to the need for continued attention to not only the healthcare needs but the welfare, housing, employment and overall quality of life to support the long-term mental health of refugees and non-refugee populations alike.

\section{Competing interests}

The authors declare that they have no competing interests.

\section{Authors' contributions}

OOA was involved in the conceptualisation of the study, designed the questionnaire, was involved in statistical analysis and prepared some part of the text. He approved the final manuscript. ETO was involved in the conceptualisation of the study, wrote some part of the text. She approved the final manuscript. OKI was involved in the statistical analysis, wrote part of the text. She approved the final manuscript. OAP was involved in the statistical analysis and wrote part of the text. He approved the final manuscript.

\section{Acknowledgement}

The authors would like to thank Drs Uchendu, Cadmus and Nwachukwu for reading through the original manuscript and making useful suggestions.

\section{Author details}

'Department of Community Medicine, University College Hospital, Ibadan, Nigeria. ${ }^{2}$ Department of Community Medicine, College of Medicine, University of Ibadan, Ibadan, Nigeria.

Received: 4 November 2011 Accepted: 26 July 2012 Published: 31 July 2012

\section{References}

1. Ellis BH, MacDonald HZ, Lincoln AK, Cabral HJ: Mental health of Somali adolescent refugees: the role of trauma, stress, and perceived discrimination. J Consult Clin Psychol 2008, 76(2):184.
2. Sachs E, Rosenfeld B, Lhewa D, Rasmussen A, Keller A: Entering exile: Trauma, mental health, and coping among Tibetan refugees arriving in Dharamsala, India. J Trauma Stress 2008, 21(2):199-208.

3. Lindencrona F, Ekblad S, Hauff E: Mental health of recently resettled refugees from the Middle East in Sweden: the impact of preresettlement trauma, resettlement stress and capacity to handle stress. Social psychiatry and psychiatric epidemiology 2008, 43(2):121-131.

4. Tang SS, Fox SH: Traumatic experiences and the mental health of Senegalese refugees. J Nerv Ment Dis 2001, 189(8):507.

5. Porter M, Haslam N: Predisplacement and postdisplacement factors associated with mental health of refugees and internally displaced persons. JAMA: the journal of the American Medical Association 2005, 294(5):602-612.

6. WHO: Mental health of refugees, internally displaced persons and other populations affected by conflict [Internet]. WHO. [cited 2012 May 14]. Available from: http://www.who.int/hac/techguidance/pht/ mental_health_refugees/en/.

7. Fazel M, Wheeler J, Danesh J: Prevalence of serious mental disorder in 7000 refugees resettled in western countries: a systematic review. Lancet 2005, 365(9467):1309-1314

8. Shackman G, Liu Y, Wang X: Brief review of world quality of life. 2005.

9. Ogunjobi O: Analysis of the travel patterns of the refugees: a case study of refugee camp. Ogun State, Nigeria: Oru-ljebu; 2004.

10. Onakomaiya S, Odugbemi O, Oyesiku O, Ademiluyi I: Ogun State: Local and regional perspectives. Ago-Iwoye. Nigeria: Centre for Sandwich Programmes (CESAP), Ogun State University; 2000.

11. Amoran OE, Lawoyin TO, Oni OO: others. Risk factors associated with mental illness in Oyo State, Nigeria: A Community based study. Annals of general psychiatry 2005, 4(1):19.

12. Lecrubier $Y$, Sheehan DV, Weiller E, Amorim P, Bonora I, Harnett Sheehan K, et al: The Mini International Neuropsychiatric Interview (MINI). A short diagnostic structured interview: reliability and validity according to the CIDI. European Psychiatry 1997, 12(5):224-231.

13. Harper A, Power M: Development of the World Health Organization WHOQOLBREF quality of life assessment. Psychol Med 1998, 28:551-558.

14. Florida Department of Health: Florida MAPP Field Guide [Internet]. [cited 2012 May 14]. Available from: http://www.doh.state.fl.us/compass/Resources/ FieldGuide/1MAPPIntroduction/intro.htm.

15. Gureje O, Kola L, Afolabi E, Olley BO: Determinants of quality of life of elderly Nigerians: results from the Ibadan study of ageing. African journal of medicine and medical sciences 2008, 37(3):239.

16. De Jong JP, Scholte WF, Koeter MWJ, Hart AAM: The prevalence of mental health problems in Rwandan and Burundese refugee camps. Acta Psychiatr Scand 2000, 102(3):171-177.

17. Adewuya AO, Afolabi MO, Ola BA, Ogundele OA, Ajibare AO, Oladipo BF: Psychiatric disorders among the HIV-positive population in Nigeria: a control study. J Psychosom Res 2007, 63(2):203-206.

18. Screening for co-occuring disorders using the Modified MINI Screen (MMS) User's Guide. New York: New York City Department of Health and Mental Hygiene; 2005.

19. QOL Projects. Community Quality of Life: A health promotion approach to understanding communities [Internet]. [cited 2012 May 14]. Available from: http://www.utoronto.ca/qol/communit.htm.

20. Saraceno B, Saxena S, Maulik PK: Mental health problems in refugees. Psychiatry in Society 2002, 193-220.

21. Eisenman DP, Gelberg L, Liu H, Shapiro MF: Mental health and healthrelated quality of life among adult Latino primary care patients living in the United States with previous exposure to political violence. JAMA: the journal of the American Medical Association 2003, 290(5):627-634.

22. Patel V, Flisher AJ, Hetrick S, McGorry P: Mental health of young people: a global public-health challenge. Lancet 2007, 369(9569):1302-1313.

23. Saxena S, Orley J, et al: Quality of life assessment: the World Health Organization perspective. European psychiatry 1997, 12:263s-266s.

24. Ekblad S, Roth G: Diagnosing posttraumatic stress disorder in multicultural patients in a Stockholm psychiatric clinic. J Nerv Ment Dis 1997, 185(2):102.

25. Gureje O, Olowosegun O, Adebayo K, Stein DJ: The prevalence and profile of non-affective psychosis in the Nigerian Survey of Mental Health and Wellbeing. World Psychiatry 2010, 9(1):50-55.

26. Temmingh H, Stein DJ, Seedat S, Williams DR: The prevalence and correlates of hallucinations in a general population sample: findings 
from the South African Stress and Health Study. African Journal of Psychiatry 2011, 14(3):211-217.

27. Kendler KS, Gallagher TJ, Abelson JM, Kessler RC: Lifetime prevalence, demographic risk factors, and diagnostic validity of nonaffective psychosis as assessed in a US community sample: the National Comorbidity Survey. Arch Gen Psychiatry 1996, 53(11):1022.

28. Sheehan DV, Lecrubier Y, Sheehan KH, Amorim P, Janavs J, Weiller E, et al: The Mini-International Neuropsychiatric Interview (MINI): the development and validation of a structured diagnostic psychiatric interview for DSM-IV and ICD-10. Journal of clinical psychiatry 1998, 59:22-33.

29. Sheehan D, Lecrubier Y, Harnett Sheehan K, Janavs J, Weiller E, Keskiner A, et al: The validity of the Mini International Neuropsychiatric Interview (MINI) according to the SCID-P and its reliability. European Psychiatry 1997, 12(5):232-241.

30. Schweitzer R, Melville F, Steel Z, Lacherez P: Trauma, post-migration living difficulties, and social support as predictors of psychological adjustment in resettled Sudanese refugees. Australian and New Zealand Journal of Psychiatry 2006, 40(2):179-188.

31. Ghazinour M, Richter J, Eisemann M: Quality of life among Iranian refugees resettled in Sweden. J Immigr Heal 2004, 6(2):71-81.

32. Sundquist J, Behmen-Vincevic A, Johansson SE: Poor quality of life and health in young to middle aged Bosnian female war refugees: a population-based study. Public Health 1998, 112(1):21-26.

33. Katschnig H: Methods for Measuring Social Adjustment. In Methodology in Evaluation of Psychiatric Treatment. Vienna: Proceedings of a Workshop Held in Vienna; 2011:205. 10-13 June 1981.

34. Shrestha NM, Sharma B, Van Ommeren M, Regmi S, Makaju R, Komproe I, et al: Impact of torture on refugees displaced within the developing world. JAMA: the journal of the American Medical Association 1998, 280(5):443-448.

35. Broring G, Van Duifhuizen R: Mobility and the spread of HIV/AIDS: a challenge to health promotion. AIDS Health Promot Exch 1993, (1):1-3.

36. Fox SH, Tang SS: The Sierra Leonean refugee experience: Traumatic events and psychiatric sequelae. J Nerv Ment Dis 2000, 188(8):490.

37. Stein $B N$ : The experience of being a refugee: Insights from the research literature. In Refugees and mental. Edited by Williams CL, Westermeyer J. New York: Oxford University Press; 1986:5-23. Available at: https://www.msu. edu/course/pls/461/stein/MNREXP1.htm; Accessed: 28/07/2012.

38. Hermansson AC, Timpka T, Thyberg M: The mental health of warwounded refugees: an 8-year follow-up. J Nerv Ment Dis 2002, 190(6):374.

39. Maximova K, Krahn H: Health Status of Refugees Settled in Alberta: Changes Since Arrival. Canadian Journal of Public Health 2010, 101(4):322-6.

40. Mollica RF, Sarajlić N, Chernoff M, Lavelle J, Vuković IS, Massagli MP: Longitudinal study of psychiatric symptoms, disability, mortality, and emigration among Bosnian refugees. JAMA: the journal of the American Medical Association 2001, 286(5):546-54.

41. Arrighi HM, Hertz-Picciotto I: The evolving concept of the healthy worker survivor effect. Epidemiology 1994, 5(2):189-196.

42. $L i C Y$, Sung FC: A review of the healthy worker effect in occupational epidemiology. Occupational Medicine 1999, 49(4):225-9.

43. Eisen EA, Holcroft CA, Greaves IA, Wegman DH, Woskie SR, Monson RR: A strategy to reduce healthy worker effect in a cross-sectional study of asthma and metalworking fluids. American journal of industrial medicine 1997, 31(6):671-7.

44. Berk RA: An introduction to sample selection bias in sociological data. Am Sociol Rev 1983, 48(3):386-398.

45. Hamill R, Wilson TD, Nisbett RE: Insensitivity to sample bias: Generalizing from atypical cases. J Personal Soc Psychol 1980, 39(4):578.

46. Lustig SL, Kia-Keating M, Knight WG, Geltman P, Ellis H, Kinzie JD, et al: Review of child and adolescent refugee mental health. Journal of the American Academy of Child \& Adolescent Psychiatry 2004, 43(1):24-36.

47. Rumbaut RG: Mental health and the refugee experience: A comparative study of Southeast Asian refugees. In Southeast Asian mental health. Edited by Owan CT. Washington DC: Treatment, prevention, services, training, and research; 1985:433-486. Available at: http://eric.ed.gov/PDFS/ ED266199.pdf; Accessed: 28/07/2012.

\section{doi:10.1186/1756-0500-5-394}

Cite this article as: Akinyemi et al:: Comparative study of mental health and quality of life in long term refugees and host populations in Oru-ljebu, Southwest Nigeria. BMC Research Notes 2012 5:394.

\section{Submit your next manuscript to BioMed Central and take full advantage of:}

- Convenient online submission

- Thorough peer review

- No space constraints or color figure charges

- Immediate publication on acceptance

- Inclusion in PubMed, CAS, Scopus and Google Scholar

- Research which is freely available for redistribution 